\title{
Penyakit Refluks Gastroesofageal Berat (PRGE) pada Anak dengan Riwayat Gizi Buruk dan Kelahiran Prematur
}

\author{
Pramita G.D. Poerwantoro, ${ }^{*}$ Yuni Astria \\ Departemen Ilmu Kesehatan Anak Fakultas Kedokteran Universitas Indonesia- Rumah Sakit \\ Dr. Cipto Mangunkusumo Jakarta
}

\begin{abstract}
Abstrak
Penyakit refluks gastroesofageal berat (PRGE)adalah gerakan retrograd isi lambung ke kerongkongan. Pada prematuritas, kelemahan peristaltik esofagus terjadi akibat kurangnya relaksasi reseptif bersihan material refluks ke esofagus. Penyakit ini menyebabkan penurunan kualitas hidup dan komplikasi. Laporan ini bertujuan menggambarkan kasus PRGE parah pada anak marasmik dengan kelahiran prematur. Kasus berasal dari seorang anak perempuan berusia tiga tahun dirawat di Rumah Sakit Umum Cipto Mangunkusumo karena menderita muntah terus-menerus setiap kali setelah menyusu. Pasien lahir prematur pada usia kehamilan 31 minggu dengan berat lahir 900 gram, mengalami malnutrisi berat dan keterlambatan perkembangan. Pasien menjalani prosedur endoskopi, pemeriksaan histopatologi dan didapatkan esofagitis berat, gastritis erosif, striktur pilorik, dan refluks laringofaringeal (LPR).Pasien diberikan proton pump inhibitors (PPIs), menjalani dilatasi pilorik satu kali dan pemasangan nasogastricjejunal feeding tube (NJFT), serta susu formula khusus medium chain tryglyceride (MCT) enam kali sehari. Dalam 18 bulan masa tindak lanjut, pasien menunjukkan peningkatan skor $\mathrm{Z}$ berat-berdasarkan-panjang badan, panjang berdasarkan usia dan lingkar kepala berdasarkan usia.Dalam menangani bayi prematur, harus mempertimbangkan PRGE sebagai salah satu etiologi pertumbuhan yang terganggu. Prosedur endoskopi dan pemasangan NJFT untuk terapi nutrisi jangka panjang mengurangi komplikasi dan meningkatkan kualitas hidup.Follow up intensif diperlukan agar mencapai pertumbuhan dan perkembangan optimal.
\end{abstract}

Kata kunci: anak, komplikasi, GERD, lahir prematur, proton pump inhibitors

\section{Severe Gastroesophageal Reflux Disease in Malnourished Children with History of Prematurity}

\begin{abstract}
Gastroesophageal reflux disease (GERD) is an involuntary retrograde propulsion of gastric contents to esophagus. In prematurity, esophagus peristaltic weakness due to lack of receptive relaxation contribute to inadequate cleaning of material reflux to esophagus which become GERD predisposition. Furthermore, GERD can cause a decline of quality of life and various complications. This report aimed to describe severe GERD case in a marasmic child with premature birth. A 36-month-old girl was hospitalized at dr. Cipto Mangunkusumo General Hospital because of persistent vomitus after every milk feeding. She was prematurely born at 31 weeks of gestation with birthweight of 900 grams, and become severely malnourished with developmental delayed. She then underwent gastrointestinal endoscopic procedure and histopathology examination that revealed a severe esophagitis, erosive gastritis, pyloric stricture, and laryngopharyngeal reflux (LPR). She was treated with proton pump inhibitors (PPI) and underwent one-time pyloric dilatation with nasogastricjejunal feeding tube (NJFT) insertion and continued with medium chain triglycerides formula six times a day. At 18-month follow-up, weight-for-length $Z$ score, length-for-age and head circumference $Z$ score are increased.In dealing with premature baby, we should consider GERD as one of growth faltering etiologies. Endoscopy procedure followed by NJFT insertion for long-term nutrition therapy in severe GERD are the cornerstones to reduce complications and to improve quality of life. Moreover, close follow up for optimal growth and development should be done in such case.
\end{abstract}

Keywords: children, complications, GERD, premature birth, proton pump inhibitors

*PGD: Penulis Koresponden; E-mail:pramitagd@yahoo.com 


\section{Pendahuluan}

Refluks gastroesofageal (RGE) merupakan fenomena fisiologis yang banyak dijumpai pada bayi prematur. ${ }^{1}$ Refluks gastroesofageal didefinisikan sebagai dorongan involunter isi lambung ke esofagus yang besifat retrograd, dapat disertai ataupun tanpa regurgitasi. ${ }^{2}$ Hampir $70 \%$ bayi hingga usia tiga sampai empat bulan akan mengalami regurgitasi. Insidens RGE terjadi sebanyak $71,2 \%$ pada bayi prematur yang bergejala serta $61,1 \%$ yang asimtomatik. ${ }^{1}$ Refluks gastroesofegeal dianggap fisiologis apabila tidak menimbulkan gejala. Apabila RGE disertai dengan tanda dan gejala yang mengganggu kualitas hidup, maka disebut penyakit refluks gastroesofageal (PRGE). ${ }^{1,2}$

Penyakit refluks gastroesofageal (PRGE) dapat menimbulkan komplikasi respiratori dan non respiratori seperti pneumonia, apnea, batuk kronik, sinusitis, laryngitis, otitis media, gangguan makan atau gangguan tidur, esofagitis, hematemesis, anemia, bahkan gangguan tumbuh kembang jangka panjang. ${ }^{1}$ Sayangnya, penentuan diagnosis PRGE tidak mudah karena belum ada metode diagnosis PRGE yang dapat diandalkan sepenuhnya, baik secara teknis maupun validitas hasil termasuk pemberian terapi antirefluks yang tidak tepat sasaran yang akan memengaruhi prognosis. ${ }^{3,4}$ Gangguan neurologis, kelahiran prematur serta berat lahir rendah akan memberikan luaran lebih buruk dibandingkan refluks fisiologis. ${ }^{5}$

Penanganan jangka panjang sangat penting pada pasien PRGE berat dan memerlukan keterlibatan tim multidisiplin. ${ }^{6}$ Laporan kasus longitudinal ini bertujuan untuk deteksi dini dan penanganan komplikasi jangka pendek dan panjang PRGE berat yang disertai berbagai komorbiditas.

\section{Laporan kasus}

Pasien seorang anak perempuan 1 tahun 2 bulan (usia koreksi), berat badan 5,22 kg datang ke poliklinik gastroentero-hepatologi Kiara Rumah Sakit Umum Pusat Nasional Cipto Mangunkusumo (RSUPNCM) pada tanggal 4 Januari 2018 karena muntah hilang-timbul sejak 13 bulan yang lalu. Tiga belas bulan yang lalu, pasien mengalami muntah $2-3 \times$ /hari tiap minum, minum tanpa selang nasogastrik (NGT) dengan formula SGM BBLR ${ }^{\circledR} 8 \times 60 \mathrm{~mL}$. Kenaikan berat badan (BB) sebesar 195 gram dalam waktu tiga minggu setelah pulang perawatan di neonatal intensive care unit (NICU) RSCM. Pasien diberikan formula SGM BBLR $^{\circledR}$ dan Infatrini ${ }^{\circledR}$ dengan frekuensi pemberian tiap tiga jam per oral (orang tua belum setuju pemasangan NGT). Volume sekali pemberian berkisar 75-90 mL, namun kebanyakan pasien hanya mampu menerima $75 \mathrm{~mL}$; selebihnya dimuntahkan. Dalam periode tersebut, pasien juga sempat mendapatkan omeprazole $0,7 \mathrm{mg} / \mathrm{kg} / \mathrm{hari}-1 \times 1,5 \mathrm{mg}$ per oral di poliklinik nutrisi dan metabolik selama dua minggu. Keluhan muntah mulai berkurang namun sesekali masih ada. Pertambahan berat badan dalam waktu empat bulan yaitu 1,360 gram - 2 gram $/ \mathrm{kg} / \mathrm{hari}$.

Pasien rutin kontrol ke poli nutrisi metabolik setiap bulannya, pada setiap kunjungan, keluhan yang didapatkan pada pasien adalah masih muntah. Sejumlah formula yang diberikan pada pasien antara lain, Infatrini ${ }^{\circledR} 8 \times 75 \mathrm{~mL}$, F-100 $8 \times 100$, kemudian naik bertahap $120 \mathrm{~mL}$ hingga $150 \mathrm{~mL}$. Akan tetapi tidak terjadi kenaikan berat badan, kalaupun ada hanya 2 $\mathrm{g} / \mathrm{kg} / \mathrm{hari}$. Hal tersebut karena pasien sering muntah terutama saat volume $150 \mathrm{~mL}$.

Pasien dirujuk ke poli gastroenterohepatologi, saat datang pasien tidak ada demam, tidak batuk atau pilek, muntah terakhir pagi sebelum ke poliklinik, frekuensi $1 \times$ volume $<1 / 2$ gelas aqua isi susu. BAB ada $1 \times /$ hari, konsistensi lunak, BAK ada, jumlah dan frekuensi kesan dalam batas normal. Pasien didiagnosis kemugkinan PRGE lalu diberikan omeprazole 2x6 
$\mathrm{mg}$ - $3 \mathrm{~mL}$ (per oral, PO) dan direncanakan pemasangan nasogastricjejuno feeding tube (NJFT). Esofagogastroduodenoskopi (EGD) dan pemasangan NJFT dilaksanakan pada tanggal 10 Januari 2018. Asupan nutrisi diganti menjadi Pregestimil ${ }^{\circledR} 6 \times 90 \mathrm{~mL}$. Pasca pemasangan NJFT pasien masih muntah dengan frekuensi hingga $8 \times /$ hari. Pasien diberikan terapi anti-refluks dengan omeprazole $2 \times 10 \mathrm{mg}-5 \mathrm{~mL}$ PO 1 jam sebelum minum.

Riwayat penyakit dahulu, pasien lahir dari kehamilan pertama secara sectio caesaria atas indikasi gawat janin (absent end diastolic flow) di RSUPNCM saat usia kehamilan 31 minggu. Lahir dari ibu dengan faktor risiko infeksi berupa penyakit tuberkulosis dalam pengobatan obat anti-tuberkulosis (OAT). Berat lahir 900 gram (bayi berat lahir rendah, BBLR), panjang badan $36 \mathrm{~cm}$, linkar kepala $32 \mathrm{~cm}$, saat lahir bayi tidak langsung menangis dan mendapatkan resusitasi aktif selama 20 menit.

Pasien kemudian dirawat di neonatal intensive care unit (NICU) selama 40 hari. Selama perawatan di NICU, pasien baru dapat minum per oral pada usia 22 hari (kronologis) dan mendapat terapi Dexamethasone: A Randomized Trial (DART) selama 10 hari karena bronchopulmonary dysplasia (BPD). Usia 65 hari (usia koreksi 40 minggu), BB pasien 2005 gram, toleransi minum per oral baik, klinis dan hemodinamik stabil pasien diizinkan rawat jalan. Selama perawatan, pasien mendapatkan nutrisi BBLR dengan volume disesuaikan seiring pertambahan usia dan berat badan. Akan tetapi paramater pertumbuhan pasien tidak baik, terlihat melalui kurva Fenton pasien.

Riwayat perkembangan, pasien mengalami keterlambatan di keempat ranah: saat datang ke poli gastroenterohepatologi pasien belum mampu duduk, tengkurap sudah bisa dengan dibantu, mengucap kata hanya mengoceh. Pasien memiliki riwayat pengobatan valgansiklovir selama enam minggu untuk mengatasi infeksi sitomegalovirus kongenital (IgG dan IgM CMV reaktif) dan saat evaluasi PCR CMV sudah tidak terdeteksi virus pada akhir pengobatan.

Pada pemeriksaan fisik pasien tampak sadar, kontak adekuat, laju nadi $128 \times /$ menit, teraba kuat, regular, napas $28 \times /$ menit, regular, suhu $36,8^{\circ} \mathrm{C}$. Pada pemeriksaan mata didapatkan strabismus; pemeriksaan jantung tidak didapatkan murmur tanpa gallop; abdomen supel, bising usus positif normal, timpani, tidak ada organomegali; kekuatan motorik didapatkan penurunan dengan refleks fisiologis kesan meningkat.

Pemeriksaan Brainstem Evoked Response (BERA) dan Otoacoustic Emissions Test (OAE) dalam batas normal. Rinofaringolaringoskopi (RFL) pada Agustus 2018 menunjukkan laringomalasia dan disfagia. Laringomalasia sudah tidak dijumpai pada pemeriksaan RFL bulan Agustus 2019.

\section{Diskusi}

Pemantauan berkelanjutan terhadap pasien dikerjakan secara komprehensif karena pasien lahir prematur disertai PRGE berat dan termasuk dalam bayi risiko tinggi. Bayi risiko tinggi merupakan kelompok bayi yang secara klinis belum menunjukkan hambatan perkembangan tapi berpotensi mengalami gangguan akibat faktor risiko biologis, intervensi medis, lingkungan psikososial, maupun sosial ekonomi yang dialami sejak masa konsepsi sampai masa neonatal. Sayangnya, saat bertemu dengan pengamat pasien telah berusia 1 tahun 3 bulan (usia koreksi) telah ada PRGE berat disertai keterlambatan perkembangan yang nyata pada semua ranah, status gizi buruk, perawakan sangat pendek dan mikrosefali.

Kondisi RGE merupakan kondisi fisiologis pada seorang individu sehat berupa dorongan isi lambung ke esofagus yang dapat terjadi beberapa kali setiap harinya. Umumnya episode RGE berlangsung <3 menit, terjadi setelah makan atau minum (post-prandial) dan hanya sedikit menimbulkan gejala atau tidak bergejala sama sekali. ${ }^{7}$ Gejala utama RGE, yaitu regurgitasi, umumnya menurun seiring pertambahan usia. 
Kejadian RGE pada usia 12 bulan hanya 4-5\%. Disebut sebagai PRGE apabila RGE disertai dengan gejala lainnya serta menimbulkan komplikasi. Pasien PRGE cenderung mengalami gangguan makan (feeding problems). ${ }^{8}$ Studi yang ada meyebutkan bahwa bayi dengan riwayat regurgitasi pada usia 6 dan 9 bulan akan mengalami risiko mengalami RGE pada usia 12-24 bulan, meski kebanyakan akan spontan dengan sendirinya pada usia 12-14 bulan terutama bayi yang sehat. ${ }^{7}$ Bayi yang mengalami regurgitasi lebih dari 90 hari selama dua tahun pertama kehidupannya berisiko 2.3 kali lebih tinggi mengalami PRGE dibandingkan mereka yang tanpa regurgitasi. ${ }^{8}$ Pasien memiliki riwayat regurgitasi sejak hari pertama kelahiran, sehingga pasien termasuk kelompok risiko lebih tinggi untuk mengalami PRGE.

Patofisiologi PRGE berkaitan dengan relaksasi transient lower esophageal sphincter (TLES) dan krural diafragma namun pada semua umur terutama terkait dengan relaksasi TLES. ${ }^{2,9}$ TLES adalah otot polos yang berkontraksi secaratonik berbentuk cicin tebal membangkitkan tekanan tinggi pada gastroesophageal junction dan berfungsi sebagai barier mekanik antara lambung dan esofagus. Krural kanan diafragma melingkari TLES dan sebagai topangan tambahan (Gambar 1). Kedua struktur tersebut membangkitkan tekanan tinggi pada zona distal esofagus, akibatnya bila terdapat disfungsi pada salah satu atau kedua mekanisme tersebut maka memudahkan terjadinya RGE/PRGE. Relaksasi TLE didefinisikan sebagai penurunan tiba-tiba tekanan TLE menjadi selevel dengan tekanan intragaster yang tidak berhubungan dengan proses menelan, durasi lebih panjang yang terlihat melalui relaksasi; dipicu oleh menelan. ${ }^{2,10}$

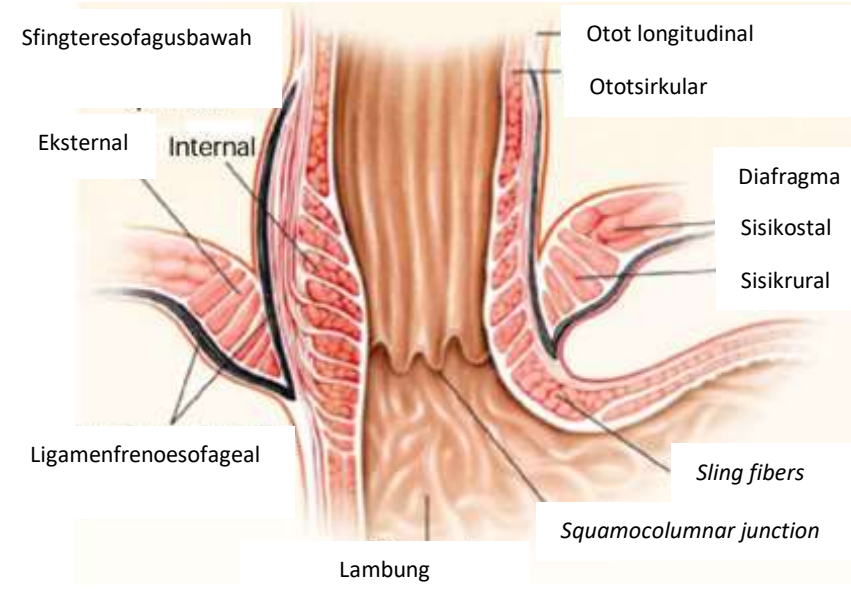

Gambar 1. Anatomi sfingter esofagus bawah (Ilustrasi gambar dari Omari et al. ${ }^{11}$ dengan modifikasi)

Pada bayi prematur terjadi kelemahan peristaltik esofagus yang berkontribusi terhadap buruknya bersihan material refluks ke esofagus. ${ }^{2}$ Relaksasi TLE dapat dipicu oleh distensi lambung dan peningkatan tekanan intra-abdomen karena peregangan, batuk, peningkatan usaha napas dan postur post-prandial. Refleks TLE merupakan refleks neural, dimediasi melalui batang otak dengan saraf vagus sebagai jalur eferen. Pengosongan lambung yang lebih lambat berkaitan dengan terjadinya PRGE, berkaitan dengan jumlah volume, osmolalitas, densitas kalori dari makanan yang dikonsumsi. Relaksasi reseptif dari lambung proksimal berdampak pula pada terjadinya relaksasi TLE. Pada bayi, relaksasi reseptif tersebut terabaikan dan hal itu dapat menjelaskan terjadinya reflkus. ${ }^{2,10}$

Material refluks (udara, cairan, atau kombinasi keduanya) memicu distensi abdomen dan proses asidifikasi yang akan memicu bersihan esofagus. Proses bersihan termasuk peristaltik primer (PP), peristaltik sekunder (PS), dan sfingter esofagus sisi atas yang mencegah masuknya refluks ke faring atau laring. Keseluruhan mekanisme pertahanan motorik esofagus dapat terlihat pada usia gestasi 33 minggu. Pasien saat kelahiran masih dalam usia gestasi 31 minggu sehingga mekanisme bersihan esofagus sangat mungkin belum terbentuk dengan baik dan mengakibatkan fungsinya tidak berjalan dengan adekuat. ${ }^{2}$ 


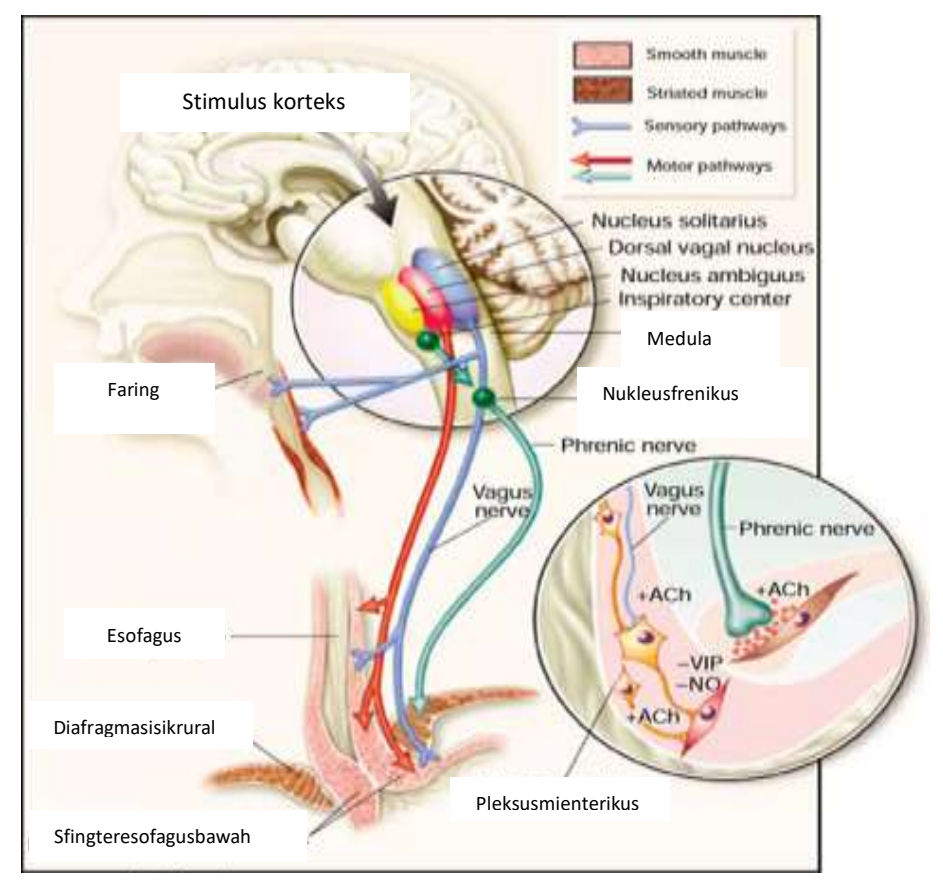

Gambar 2. Jaras refleks transient lower esophageal (Ilustrasi gambar dari Martin \& Hibbs ${ }^{9}$ dengan modifikasi)

Pada bayi, peristaltik primer meliputi respons utama esofagus terhadap refluks, setelah episode refluks, PS adalah kejadian motorik pertama terkait bersihan asam dan berperan sebagai bersihan selama tidur (Gambar 2). Gangguan peristaltik yang efektif dapat menyebabkan kerusakan mukosa, aspirasi, apnea dan bradikardia pada bayi seperti yang terjadi pada pasien saat ini, yaitu kerusakan mukosa esofagus yang bersifat kronik.

Zat yang paling merusak mukosa esofagus adalah kombinasi asam dan pepsin, pada bayi prematur mulai usia 24 minggu, kadar asam lambung sangat tinggi, ditandai dengan $\mathrm{pH}$ lambung 4 dan produksi pepsinogen terutama sejak usia gestasi 31 minggu, sesuai dengan pasien ini yang lahir pada usia gestasi 31 minggu. Kerusakan mukosa esofagus pada pasien didominasi oleh refluks dengan material berupa asam dan pepsinogen. ${ }^{2}$

Diagnosis PRGE ditegakkan dari anamnesis, pemeriksaan fisik, penunjang dan umumnya dibuat berdasarkan penilaian klinis karena sejumlah alternatif pemeriksaan penunjang yang ada terkait penegakan PRGE belum ada yang benar-benar spesifik. Gejala dan tanda terkait PRGE dapat dilihat pada tabel 1 berikut.

Tabel 1. Gejala dan tanda PRGE ${ }^{4}$

Tanda

esofagitis, striktur esofagus, Barrett's esophagus, pneumonia rekurens, anemia, erosi dental, penolakan minum, dystonic neck posturing (Sandifer syndrome), Apnea spells, kejadian mengancam nyawa yang nyata

Gejala

regurgitasi berulang dengan atau tanpa muntah, hilangnya berat badan atau kenaikan BB tidak adekuat, iritabiltias pada bayi, perilaku ruminasi, rasa panas atau nyeri dada (untuk anak >10 tahun), hematemesis, disfagia, odinofagia, mengi, stridor, 
Sejumlah red flags PRGE yang harus diwaspadai pada seorang bayi atau anak antara lain: (1) kesulitan makan (feeding problems), (2) perdarahan gastrointestinal, (3) nyeri perut, (4) masalah pernapasan seperti batuk kronik berulang, asma, otitis media akut, apnea, aspirasi pneumonia (5), penambahan berat badan yang tidak adekuat (failure to thrive), ${ }^{2,8,12,13}$

Kesulitan makan (feeding problems) didefinisikan sebagai penolakan dari seorang anak terhadap makan atau membuka mulut untuk makan meski sedang lapar; atau makanan disimpan di dalam mulut untuk waktu yang lama (tidak menginginkan atau tidak menelan makanan); atau selalu memuntahkan makanan yang sudah ditelan. Definisi lainnya dapat pula berarti membutuhkan waktu yang lama untuk menghabiskan makanan atau ibu merasa tidak nyaman sewaktu melihat kebiasaan makan anaknya. ${ }^{8}$ Saat menginterpretasikan muntah perlu diperhatikan jumlah dan frekuensi nutrisi yang diberikan, posisi selama pemberian minum, bersendawa, dan perilaku selama menyusui.

Pada pasien gejala PRGE yang ada berupa kesulitan makan, pasien selalu memuntahkan makanan cair yang diberikan, baik secara oral, NGT dengan volume bervariasi. Regurgitasi dan muntah berulang terutama terjadi sejak usia 6 bulan (usia koreksi 4 bulan) dengan frekuensi 2-3x/hari dan volume $+/-10-15 \mathrm{~mL}$ menggunakan formula BBLR. Meski telah dilakukan pemasangan NJFT, pasien masih tetap mengalami muntah dan pertumbuhan BB belum adekuat. Hal tersebut dikarenakan pasien masih diberikan minum saat malam hari atau saat tidur, padahal saat malam hari terjadi sejumlah perubahan pada proses percernaan terkait irama sirkadian seperti keterlambatan pengosongan lambung, peningkatan produksi asam lambung, penurunan laju menelan, penurunan tekanan sfingter esofagus bagian bawah. ${ }^{9,10}$ Saat tidur, kejadian refluks dibandingkan saat bangun memang lebih sedikit akan tetapi lama paparan dengan asam lebih lama karena penurunan bersihan esofagus sehingga potensi kerusakan mukosa akan lebih tinggi. ${ }^{10}$

Studi yang ada menyatakan bahwa empat jam post prandial merupakan waktu terbaik untuk bersihan volume cairan yang masuk ke lambung, karenanya pemberian makan pada anak disarankan tiap empat jam. ${ }^{9}$ Pasien saat ini sudah diberikan tiap 3,5 jam $(6 \times /$ hari $)$ sebanyak 75-90 mL per kali selang-seling dengan formula Peptamen ${ }^{\circledR}$ dengan takaran 2,5 - 3 sdt per pemberian dengan drip selama satu jam. Muntah setelah minum sudah sangat jarang, kadang satu kali/hari volume $5 \mathrm{~mL}$.

Berdasarkan kurva pertumbuhan pasien, semua parameter tidak menunjukkan hasil yang memuaskan, kurva BB/U selalu di bawah -3 Z score meski ada pertambahan. Serupa dengan $\mathrm{PB} / \mathrm{U}$, grafik cenderung mendatar, hampir setiap pengukuran selalu di bawah $-3 \mathrm{Z}$ score. $\mathrm{BB} / \mathrm{TB}$ juga memberikan gambaran tidak adekuatnya pertambahan sehingga selalu di bawah $-3 \mathrm{Z}$ score, pasien dapat dikatakan mengalami failure to thrive. Pola tersebut telah terjadi sejak perawatan sebelumnya saat pasien lahir, terlihat melalui kurva Fenton yaitu berat badan, panjang badan hingga lingkar kepala selalu di bawah persentil 3. Hingga usia satu bulan, pertumbuhan lingkar kepala masih normal, namun setelahnya kurva lingkar kepala pasien selalu di bawah $-3 \mathrm{Z}$ score. Hal ini menunjukkan bahwa pasien mengalami malnutrisi yang kronis yang dapat diakibatkan oleh refluks yang diderita oleh pasien.

Pemilihan modalitas diagnostik berupa endoskopi dan pengambilan jaringan melalui biopsi dengan pertimbangan keduanya dapat dipercaya sebagai alat diagnositk penentuan PRGE pada pasien ini. Hasil endokospi menggambarkan esofagitis berat, gastritis, LPR. Esofagitis merupakan gambaran kronik akibat inflamasi berulang oleh paparan asam di daerah esofagus akibat refluks berulang yang belum teratasi selama ini.

Biopsi menggambarkan kelainan berupa esofagitis berat yaitu ditandai dengan hiperplasia sel epitel basal serta erosi dan ulserasi. Esofagitis berat pada kasus ini mengarah kepada refluks 
selain karakter sel yang tidak khas eosinofilik dan pada pengambilan jaringan dilakukan $1 / 3$ distal esofagus.

Tata laksana pada PRGE dapat terbagi atas dua kelompok, non-farmakalogi dan farmakologi. Terapi non-farmakologi meliputi modifikasi gaya hidup seperti body positioning, cara pemberian makan, feed thickening, penggunaan formula hidrolisat, dan intragastric tubes. (1) Body positioning, banyak digunakan untuk penanganan konservatif PRGE bayi prematur di rumah sakit (tidak dianjurkan dilakukan pada fasilitas tanpa monitoring kardiovaskular dan respiratori karena dapat meningkatan kejadian SIDS). ${ }^{14,15}$ (2) Cara pemberian makan, frekuensi yang lebih jarang dengan durasi lebih panjang tiap pemberian makan serta cara pemberian selang-seling seperti bolus bergantian dengan kontinu hingga seterusnya, diperkirakan dapat mengurangi kejadian refluks pada PRGE meski masih diperlukan penelitian lanjutan. (3) Feed thickening, ASI/formula yang dikentalkan dengan sejumlah bahan salah satunya tepung beras, hingga saat ini masih pro-kontra namun dari sisi kontra dipikirkan terkait dengan necrotizing enterocolitis (NEC) dan kebutuhan nutrisi apabila dikentalkan. (4) Formula hidrolisat, disarankan bagi bayi/anak dengan PRGE karena dapat mempercepat waktu pengosongan lambung, sebab jika terjadi gangguan fungsi lambung maka dapat terjadi eksaserbasi PRGE. (5) Intragastric tubes, ketidakmampuan bayi prematur untuk koordinasi menghisap, menelan, dan bernapas, feeding tube secara rutin digunakan di NICU.

Tetapi, keberadaan NGT dapat memicu terjadinya PRGE melalui dua mekanisme berikut, pertama melemahkan sfingter esofagus bawah sehingga memicu reflkus ke esofagus, kedua mengganggu bersihan esofagus. Agar mencegah hal tersebut, maka dapat dipilih cara dengan penggantian NGT tiap pemberian bolus meski perlu dipikirkan pula efek sampingnya seperti

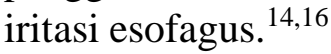

Pada pasien ini dilakukan cara pemberian makan dengan durasi lebih panjang tiap pemberian makan dan frekuensi dikurangi, tiap 4 jam dengan lama 1 jam tiap pemberian, hal itu senada dengan fisiologis saluran cerna termasuk saat tidur. Pada pasien diberikan formula hidrolisat, Pregestemil $^{(\mathrm{R})}$ lalu Peptamen ${ }^{(\mathrm{R})}$ yang mengandung protein hidrolisat ekstensif via NJFT dan kemudian saat ini Nutrinidrink ${ }^{\circledR} 150 \mathrm{~mL}$ tiap 4 jam.

Terapi farmakologi pada pasien berupa pemberian omeprazole dengan dosis terakhir $10 \mathrm{mg}-$ $5 \mathrm{~mL}$ tiap 12 jam. Omeprazol merupakan golongan proton pump inhibitors (PPIs) yang bekerja mengkatalisasi fase akhir dari proses sekresi asam, mencegah sekresi asam oleh selsel parietal. PPIs dianggap lebih unggul dibandingkan H2RAs dalam mengurangi gejala terkait PRGE pada anak. Dosis pemberian PPIs disarankan dengan dosis terkecil mengingat efek sampingnya berupa peningkatan risiko terjadinya infeksi bakteri dan mengganggu keseimbangan mikrobiota usus. Selain itu, efektivitas penggunaan PPIs sebagai terapi PRGE masih kontroversi, sebab pada beberapa penelitian tidak didapatkan perbedaan yang signifikan dalam menurunkan gejala PRGE baik pada yang diberikan ataupun tidak diberikan PPIs. Pemberian PPIs dapat dikatakan sangat bergantung indikasi dan keputusan penilain klinis. ${ }^{17}$

Esofagitis berat yang terjadi pada pasien merupakan komplikasi yang diakibatkan oleh PRGE yang diderita selama ini. Esofagitis merupakan komplikasi intra esofagus yang terjadi karena paparan asam yang terus menerus sehingga timbul inflamasi. Selain itu, didapatkan pula komplikasi respirasi pada pasien saat masih perawatan berupa bronchopulmanry dysplasia (BPD). Studi oleh Omari, et al. menyatakan bahwa RGE dapat mengeksaserbasi timbulnya BPD bahkan hingga sudden infant death syndrome (SIDS). ${ }^{11}$ Pada pasien juga didapatkan LPR yang timbul akibat inflamasi kronik sehingga sfingter esofagus tidak berfungsi dengan optimal dan asam lambung secara terus menerus naik ke esofagus. ${ }^{5}$ 
Dengan tata laksana yang diberikan selama ini, berat badan pasien $10,11 \mathrm{~kg}$ dengan panjang badan $87 \mathrm{~cm}$ dan lingkar kepala 44,5 cm. Status gizi $\mathrm{PB} / \mathrm{U}<-3 \mathrm{SD}<\mathrm{Z}<23 \mathrm{SD}, \mathrm{BB} / \mathrm{PB}-2 \mathrm{SD}<$ $\mathrm{Z}<-1 \mathrm{SD}, \mathrm{LK}<-2 \mathrm{SD}$ (gizi baik, perawakan pendek).

\section{Kesimpulan}

Dalam menangani bayi prematur, kita harus mempertimbangkan PRGE sebagai salah satu etiologi pertumbuhan yang terganggu. Prosedur endoskopi diikuti oleh pemasangan NJFT untuk terapi nutrisi jangka panjang pada PRGE berat adalah upaya untuk mengurangi komplikasi dan meningkatkan kualitas hidup. Selain itu, follow up yang intensif diperlukan agar mencapai pertumbuhan dan perkembangan yang optimal.

\section{Daftar Pustaka}

1. Kültürsay, N. Gastroesophageal reflux (GER) in preterms: current dilemas and unresolved problems in dagnosis and treatment. Turk J Pediatr. 2012;54:561-9.

2. Czinn SJ, Blanchard S. Gastrooesophageal reflux disease in neonates and infants. Pediatr Drugs. 2013;15:19-27.

3. Birch J, Newell SJ. Gastroesophageal reflux disease in preterm infants-current management and diagnsotic dilemmas. BMJ. 2016:2-7.

4. Indrio F, Magista AM, Cavallo L, Francavilla R. Gastroesophageal reflux in Preterm Infants: How acid should it be? J Pediatr Gastroenterol Nutr. 2008;4:96-8.

5. Michail S. Gastroesophageal reflux. Pediatr Rev. 2007;3:101-9.

6. Baird DC, Harker DJ, Karmes AS. Diagnosis and treatment of gastroesophageal reflux in infants and children.AmFamPhysician. 2015;8:706-13.

7. Hegar B, Vandenplas Y. Gastroesophageal reflux in children. Paediatr Indones. 2011;6:361-8.

8. Hegar B, Alatas FS, Kadim M, Putri ND, Wardhani WI. Natural evolution of regurgitation in children aged 12-24 months: A 1-year cohort study. Indones J Gastroenterol Hepatol Dig Endos. 2013;1:13-20.

9. Martin RJ, Hibbs AM. Diagnosing Gastroesophageal Reflux in Preterm Infants. Pediatrics. 2006;2:793-4.

10. Davidson G. The role of lower esophageal sphincter function and dysmotility in gastroesophageal reflux in premature infants and in the first year of life. J Pediatr Gastroenterol Nutr. 2003;37: 517-22.

11. Omari TI, Barnett C, Snel A, Goldsworthy W, Haslam R, Davidson G. Mechanisms of gastroesophageal reflux in healthy premature infants. J Pediatr. 1998;133:650-4.

12. Omari TI, Barnett CP, Benninga MA, Lontis R, Goodchild L, Haslam RR, et al. Mechanism of gastroesophageal reflux in preterm and term infants with reflux disease. BMJ. 2002;51: 475-9.

13. Omari TI, Barnett C, Snel A, Goldsworthy W, Haslam R, Davidson G. Mechanisms of gastroesophageal reflux in healthy premature infants. J Pediatr. 1998;133:650-4.

14. Corvaglia L, Martini S, Aceti A, Arcuri S, Rossini R, Faldella G. Nonpharmacological management of gastroesophageal reflux in preterm infants. BioMed Res Int. 2013;2013:1-7.

15. Van WJK MP, Bennnga MA, Dent J, Lontis R, Goodchild L, McCall LM, et al. Effect of body position changes on postprandial gastro esophageal reflux and gastric emptying in the healthy premature neonate. $\mathbf{J}$ Pediatr. 2007;151:585-90.

16. Hadinegoro SR, Kadim M, Devaera Y, Idris NS, Ambarsari CG, editor. Konsensus gastroesofageal refluks pada bayi dan anak. Dalam: Update Management of Infectious Diseases and Gastrointestinal Disorders PKB LXIII. 2017. Jakarta: Departemen Ilmu Kesehatan Anak FKUI-RSCM.h.93-100.

17. Corvaglia L, Monari C, Martini S, Aceti A, Faldella G. Pharmacological therapy of gastroesophageal reflux in preterm infants. BioMed Res Int. 2013;714564:1-12. 